\title{
Ice stream behaviour and deglaciation of the Scandinavian Ice Sheet in the Kuittijärvi area, Russian Karelia
}

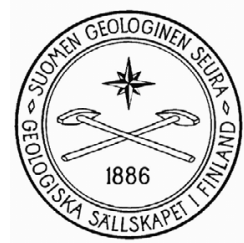

\author{
Niko Putkinen ${ }^{1) *}$ and Juha-Pekka Lunkka ${ }^{2)}$ \\ 1) Geological Survey of Finland, P.O. Box 97, FI-67101 Kokkola, Finland \\ 2) Institute of Geosciences, University of Oulu, P.O. Box 3000, \\ FI-90014, Oulun yliopisto, Finland
}

\begin{abstract}
Glacial landforms of the Lake Kuittijärvi area, Russian Karelia, which covers an area of more than $7000 \mathrm{~km}^{2}$, were studied in detail using aerial photography and satellite imagery methods and on-site field observations. This was done to reconstruct a detailed history of Scandinavian ice sheet behaviour in the Lake Kuittijärvi area. The results indicate that the Lake Tuoppajärvi sub-ice stream (TIS) that formed the northern part of the KuusamoWhite Sea ice stream and the Lake Kuittijärvi sub-ice stream (KIS), which was part of the Northern Karelian ice stream, operated in the area during the last deglaciation. Subglacially formed lineation patterns associated with other indicative landforms such as end moraines and esker ridges indicate a clear age relationship between the ice streams' activity and that the KIS was active after the linear landforms were created by the TIS. It is estimated that deglaciation of the TIS from the Kalevala end moraine to the Lake Pääjärvi end moraine took place between ca. I I 300 - 10900 calendar years ago. It seems that the terminus of the KIS marker by the Kalevala end moraine was also formed around I I 300 calendar years ago but the KIS remained active longer than the TIS. Both of these sub-ice streams terminated into a glacial lake that was part of a larger White Sea Basin ice lake.
\end{abstract}

Key words: glacial geology, glacial features, drumlins, eskers, ice-marginal features, ice streams, deglaciation, Holocene, Kuittijärvi, Republic of Karelia, Russian Federation

*Corresponding author email: niko.putkinen@gtk.fi

\section{Introduction}

The Scandinavian ice sheet (SIS) covered vast areas of northwest Russia during the Late Weichelian (Valdaian) glaciation (cf. Svendsen et al., 2004). Although most of Finland was free of ice approximately 30000 years ago (Ukkonen et al., 1999; Lunkka et al., 2001, Lunkka et al., 2004), the SIS advanced relatively fast from its centre in the Scandinavian mountains to central Finland ca. 25000 years ago and to its last glacial maximum position in the northwest Russia between 15000 - 18000 years ago (Larsen et al., 1999; Lunkka et al., 2001; Lunkka et al., 2004; Svendsen et al., 2004; Demidov et al., 2004). The ice extent during the last glacial maximum (LGM) in northwest Russia followed the line from Valdai Upland - Beloye Ozero south of Onega Lake - Vologda - Nyandoma - Vaga - Severnaya Dvina - west- 
ern shore of Kanin Peninsula (Fig. 1) (Demidov et al., 2004, 2006; Svendsen et al., 2004). The LGM ice margin in northwestern Russia was diachronous and deglaciation started in the Vologda area ca. 18000 years ago but not until ca. 16000 years ago in western Kanin Peninsula (Demidov et al., 2006). The retreat of the eastern flank of the SIS is thought to have been more or less continuous after the LGM. However, the prominent end moraine complexes such as VepsianKrestets (ca. 15000 yr ago), Luga (ca. 14000 yr ago) and Neva (ca. 13000 yr ago) and Rugozero and Kaleva in Russian Karelia and associated landforms indicate minor standstills and oscillations of the ice margin during the course of deglaciation (cf. Ekman \& Iljin 1991; Boulton et al., 2001; Saarnisto \& Lunkka 2004). According to Yevzerov (1998), the White Sea basin area west of the Kanin Peninsula was deglaciated by 11200 years ago.

It has been suggested that the SIS separated into ice streams during the course of the last deglaciation (cf. Ekman \& Iljin 1991; Boulton et al., 2001; Demidov et al., 2004, 2006). Ice streams by definition are fast-flowing bodies of ice bordered by slowly moving or stagnant ice in the ice sheets (cf. Patterson 1994; Stokes \& Clark 2003). Ice streams leave behind characteristic landform associations when the ice streams retreat (Stokes \& Clark, 2001; Dowdeswell et al., 2004). Based on the patterns of glacial landforms such as drumlins, esker chains, and end moraines, it has been possible to achieve a general picture of the ice streams that formed in Finland and Russian Karelia during deglaciation (cf. Punkari 1985; Boulton et al., 2001, Fig. 1).

According to previous investigations, there were two major SIS ice streams operating in Russian Karelia and Finland prior to and after the Younger Dryas (Fig.1, e.g. Kurimo, 1982; Punkari, 1985, 1993, 1997; Punkari \& Boulton 1995; Ekman \& Iljin 1991; Boulton et al., 2001). These ice streams were named by Punkari (1985) as the Northern Karelian Ice Stream and the Kuusamo-White Sea ice stream. According to Punkari (1985), the Northern Karelian ice stream could be further divided into the Lake Suojärvi sub-ice stream and Lake Kuittijärvi sub-ice stream (hereafter
KIS) and the Kuusamo-White Sea ice stream was divided into the Lake Onega sub-ice stream and the Lake Tuoppajärvi sub-ice stream (hereafter TIS) (Fig. 1).

The Northern Karelian ice stream (Fig. 1) was the largest ice stream in the eastern part of the SIS during the deglaciation phase that post-dates the Younger Dryas. Based on the geomorphological features mapped (Niemelä et al., 1993), the onset zone of the Northern Karelian ice stream was $380 \mathrm{~km}$ long and its trunk was $150 \mathrm{~km}$ wide. The Kuusamo-White Sea ice stream, which was situated to the north of the Northern Karelian ice stream, occupied the White Sea Basin before the Younger Dryas (Ekman \& Iljin 1991; Yevzerov, 1998; Lunkka et al., 2007). After the early part of the Younger Dryas, during the so-called Lake Pääjärvi flow stage (cf. Ekman \& Iljin, 1991), the Kuusamo-White Sea ice stream terminated at the Lake Pääjärvi end moraine zone (Fig. 1). During this flow stage, the trunk of this ice stream was only $50 \mathrm{~km}$ wide and the onset zone was approximately $100 \mathrm{~km}$ long (cf. Niemelä et al., 1993).

Boulton et al. (2001) suggested that the mass balance changes in the central part of the SIS in the Scandinavian mountains during the Younger Dryas were responsible for the initiation of these ice streams. The behaviour of the ice streams is not fully understood, but the different ice stream behaviour was most likely caused by changing physical conditions at the ice bed interface (cf. Clark, 1994; Payne \& Donkelmans, 1997; Sarala, 2007; Kleman \& Glasser, 2007).

Kleman et al. (1997) presented a model on the behaviour of the former SIS ice streams and concluded that the flow of ice streams in Russian Karelia was relatively fast and took place by a surge fan mechanism. Also, Stokes \& Clark (2003) and Sarala (2007) suggested a rapid, surge type movement of the former ice streams that operated on the eastern flank of the SIS during the last deglaciation. However, Punkari (1985) and Boulton et al. (2001) have concluded that the surge mechanism did not play any major role in the movement of ice streams on the eastern flank of the SIS. According to them deglaciation was timetransgressive without major surge-type advances and subsequent retreats. 


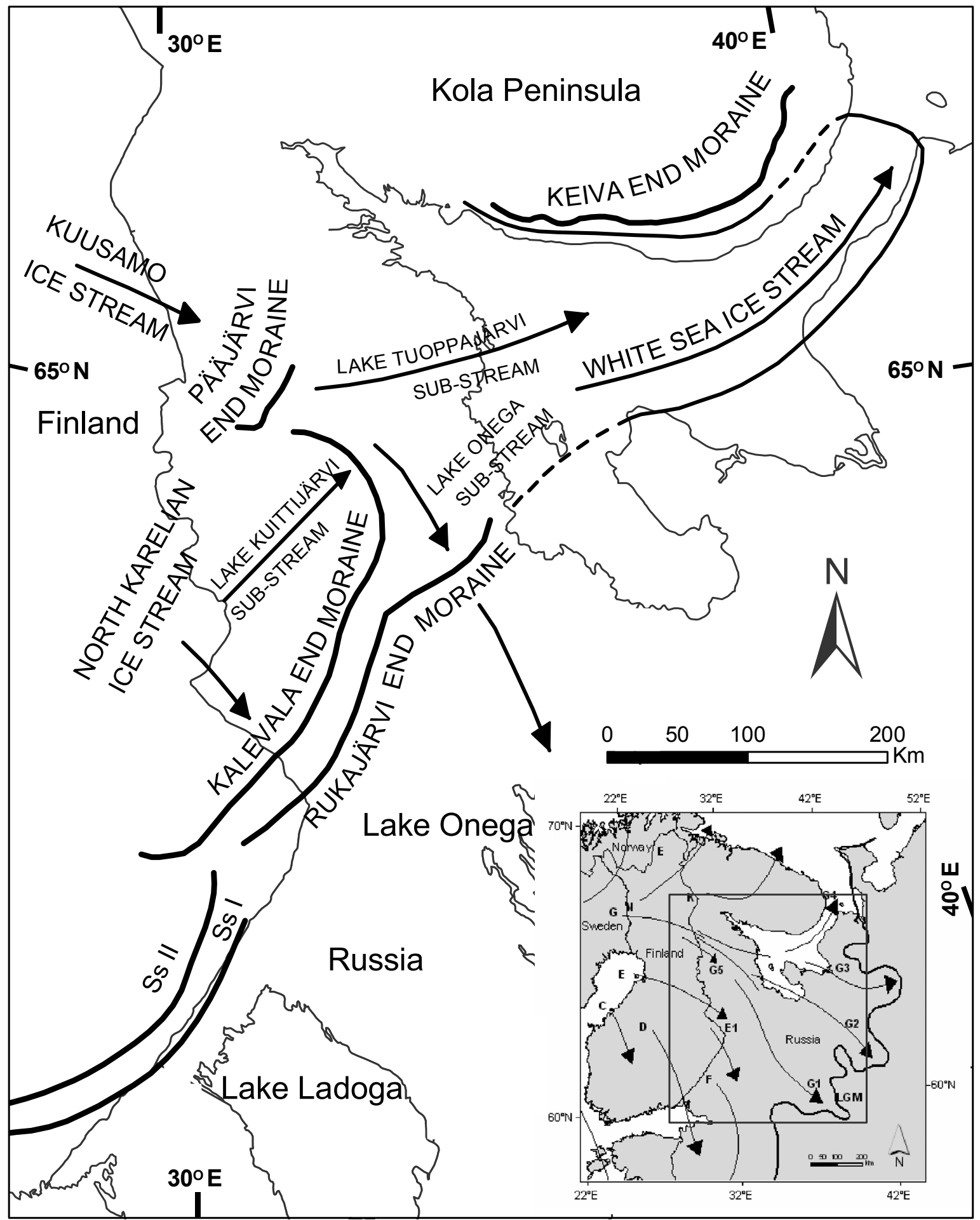

Fig. I. Location of the study area (shaded) in Russian Karelia with names of the main end moraine belts and ice streams used in text. In the inset map the main ice streams and the last glacial maximum limit of the eastern flank of the SIS are also indicated. Ice streams codes after Punkari 1995. 
In this paper, we have adopted the large scale configuration of the palaeo-ice streams from Punkari (1985) and Boulton et al. (2001) (see Fig. 1). Although the general configuration of the paleo-ice streams is relatively clear, the detailed picture of the palaeo-ice stream configuration and behaviour in space and time is unknown. As well, we have selected an area around Kuittijärvi basin, Russian Karelia where the interplay existed between the TIS and the KIS. This was done to clarify the formation and the time relationship between the two end moraine chains and the interlobate area formed by the Northern Karelian and Kuusamo - White Sea ice streams.

\section{Study area}

The study area is located in the Kalevala region, northwestern Russia (Fig. 2). The bedrock of the study area consists of the Archaean basement rocks of the Fennoscandian Shield, typically consisting of metamorphic rocks like gneisses with local granitic intrusions. Tholeitic basalts are found within northwest-southeast striking schist belts that occur in the eastern side of Kalevala town (Koistinen et al., 2001).

Generally speaking, the bedrock dictates the gently sloping topography of the study area. However, several fault zones and granite hills dominate the topog-

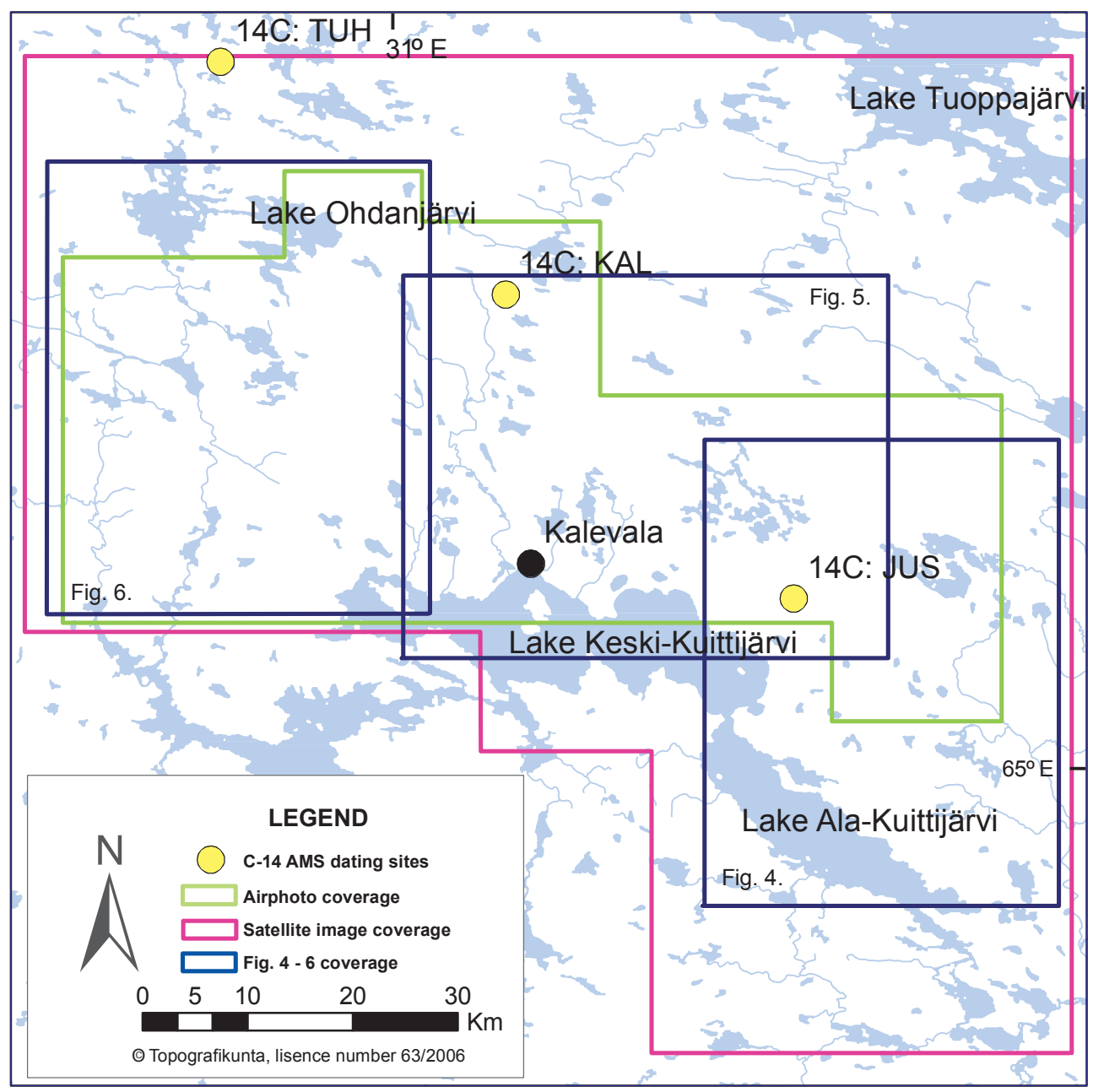

Fig. 2. Aerial photograph and satellite imagery cover of the area studied. Areas covered by figures $4-6$ and I4-C dating sites are also indicated. 
raphy in the Lake Ohdanjärvi area where the average height is about $190 \mathrm{~m}$ a.s.l., while the highest peaks are over $280 \mathrm{~m}$ a.s.l. These granite hills are megascale forms in the landscape, whereas relatively soft, metasedimentary rocks on the eastern side of Lake Kuittijärvi are relatively flat and the land surface of this area is tilted northwest towards the White Sea Basin. The average altitude in this part of the study area ranges from 100 to $130 \mathrm{~m}$ a.s.l. and the landscape is dominated by peatlands, lake basins and glacial landforms such as drumlins, eskers and end moraines.

\section{Methods}

Palaeo-ice streams leave behind characteristic landform associations when they retreat (Stokes \& Clark, 2001; Dowdeswell et al., 2004). Therefore, the study of landforms such as drumlins, drumlinoids and megaflutes, non-streamlined topography, eskers and ice marginal landforms are used to reconstruct palaeo-ice streams (Stokes \& Clark, 1999).

To understand the former ice stream behaviour in the study area during the last deglaciation, a modified land-system approach was adopted in the present work (cf. Eyles, 1983). The main glaciogenic features were mapped and their genesis was interpreted from aerial photographs, satellite imagery and field mapping. Aerial photograph and satellite imagery studies and field surveys were done in an area covering $7000 \mathrm{~km}^{2}$. Landforms in the study area were divided into those formed in a(n) 1) subglacial setting, 2) supraglacial setting and 3) ice marginal setting. The landforms and erosional marks that were categorized to form in a subglacial setting included ice flow parallel forms. Such forms include flutings and drumlins, the elongation (length / width ratio) of which is also thought to indicate the flow rate of the former ice (cf. Stokes \& Clark, 2003) and subglacial ice flow transverse forms such as various ribbed moraines as well as roches mountonnees and striations on bedrock surfaces. Also, longitudinal eskers that occur as single continuous ridges or single ridges or beads belong to this group since the majority of them are aligned parallel to the ice flow and formed subglacially or very close to the ice margin. Landforms that belong to the supraglacial setting include various dead ice hummocks composed mainly of till and kame kettle topography. Other landforms that are formed close to or at the ice margin are categorized here as discontinuous end-moraines composed of till, outwash fans, sandur plains and glaciofluvial deltas.

Geomorphological interpretation, where different landforms were defined and categorized, was carried out using a stereoscope on black and white photos, scale 1:16 000 stereo pairs from the study area. Individual observations of landforms and their information on flow patterns and ice lobe margins were manually drawn on 1:50 000 and 1:250 000 topographic maps. In addition, the ice stream flow patterns and flow dimensions were studied on a larger scale using Google Earth satellite images and the observations were drawn on 1:200 000 and 1:500 000 topographic maps.

Field observations and geological field mapping were carried out after and partially intermittently with aerial photograph interpretation during several field trips in 2003 - 2007. Unfortunately, there are no natural exposures in the study area but all gravel and shallow cable pits and ditches, and shallow test pits were used to identify the nature of material in different landforms.

The timing of deglaciation presented in this article is based on C-14 AMS dates and on relative geomorphological data and assumptions of the ice retreat rate. Sediment cores for the C-14 age determinations were collected by a Russian peat corer from small lakes. The subsamples for four C-14 age determinations were taken directly from the sediment cores. Fine detritus gyttja immediately above the laminated minerogenic sediment was chosen for dating at each sample site. The idea of using C-14 dating in this work is derived from the notion that dating results would give the minimum age of the ice margin retreat in the area, although the organic production usually starts decades after the ice has melted from the area (A. Ojala, pers. comm., 2007). C-14 AMS dating was carried out in Pozdam Radiocarbon Laboratory, Poland. C-14 dates obtained were calibrated using Calib rev 5.0.2. programme (Stuiver \& Reimer, 1993). 


\section{Results}

All the prominent geomorphological features in the Kalevala area are described and classified on maps (Figs. 3, 4, 5, 6). The geomorphological features in the study area can be grouped into 1) subglacial and 2) supraglacial and 3) ice marginal landforms. A brief description of the main geomorphological features belonging to these groups and their location is given below.

\section{I. Subglacial formations}

\section{I.I. Streamlined landforms}

A vast amount of streamlined landforms occur in the study area. These landforms are mainly drumlins, drumlinoids and flutings. Based on directions of the longitudinal axis of these formations, it is possible to differentiate three different fan-shaped lineation sets of the streamlined features (Fig. 3).

The Lake Tuoppajärvi drumlin field is situated in the northern and northeastern side of the study area (Fig. 3). Drumlins and other linear features are orientated between west northwest - east southeast and northwest - southeast indicating ice flow from the west and northwest. The maximum length of drumlins is slightly over $2 \mathrm{~km}$. They are usually 100 to $150 \mathrm{~m}$ wide and the average length is approximately one kilometre. The similar northwest - southeast orientation can be seen as an older direction of crossstriations on bedrock and as an older direction in the orientation of roches mountoinnes on the eastern side of Lake Keski-Kuittijärvi (Fig. 4).

The second drumlin field is situated in the Lake Keski-Kuittijärvi and Lake Ala-Kuittijärvi areas (Figs. 3, 4 and 5). The long axes directions of drumlins and streamlined landforms in the area range from west - east and southwest - northeast except those older northwest - southeast lineations found on the eastern side of Lake Keski-Kuittijärvi mentioned above. Based on the age relationship of the lineated land- forms, the latest ice movement in the area came from the west fanning out towards the Kalevala end moraine. The maximum length and width of drumlins in the Lake Ala- and Keski-Kuittijärvi areas is $2.5 \mathrm{~km}$ and 100 to $150 \mathrm{~m}$ respectively. The longest drumlins are found approximately $35 \mathrm{~km}$ from the Kalevala end moraine, for example, the ice stream terminus in the western side of the Lake Ala-Kuittijärvi. The size of the drumlins decreases toward the Kalevala end moraine and for example, 2 to $3 \mathrm{~km}$ from the proximal side of the end moraine the drumlins are only 1.2 to $0.6 \mathrm{~km}$ long and 100 to $200 \mathrm{~m}$ wide.

The third drumlin field, Lake Pääjärvi - Lake Ohdanjärvi drumlin field, occurs in the northwestern part of the study area (Figs. 3 and 6). Drumlins are typically $1.5 \mathrm{~km}$ long and 100 to $150 \mathrm{~m}$ wide. The long axis direction of drumlins in this area trends northwest - southeast, indicating general ice flow from the northwest.

\section{I.2. Eskers}

The majority of the esker chains in the study area follow the direction of streamlined landforms and thus the general ice movement direction (Fig. 3). Eskers in the study area are from tens of kilometres to even a few hundreds of kilometres long and normally join the end moraine complexes. The dimensions of eskers range greatly and the highest ones rise 30 to $50 \mathrm{~m}$ above the surrounding terrain.

In the area of the Lake Tuoppajärvi drumlin field, the largest glaciofluvial esker systems run from northnorthwest and west. The direction of an esker south of Lake Tuoppajävi deviates markedly from the orientation of drumlins (Fig. 3). The eskers in the Lake Hirmusjärvi - Lake Tshernojejärvi - Lake Rekojärvi Lake Suuri-Hohlajärvi area in the western part of the Lake Tuoppajärvi drumlin field are generally aligned parallel to the orientation of drumlins (Fig. 3). Two extremely large eskers, several tens of metres high, occur in the Lake Tshernojejärvi - Lake Rekojärvi area.

Fig. 3. Glacial geomorphology and the main ice marginal and interlobate zones of the Kalevala region. Modern isobases indicating present uplift in millimetres are also indicated. 


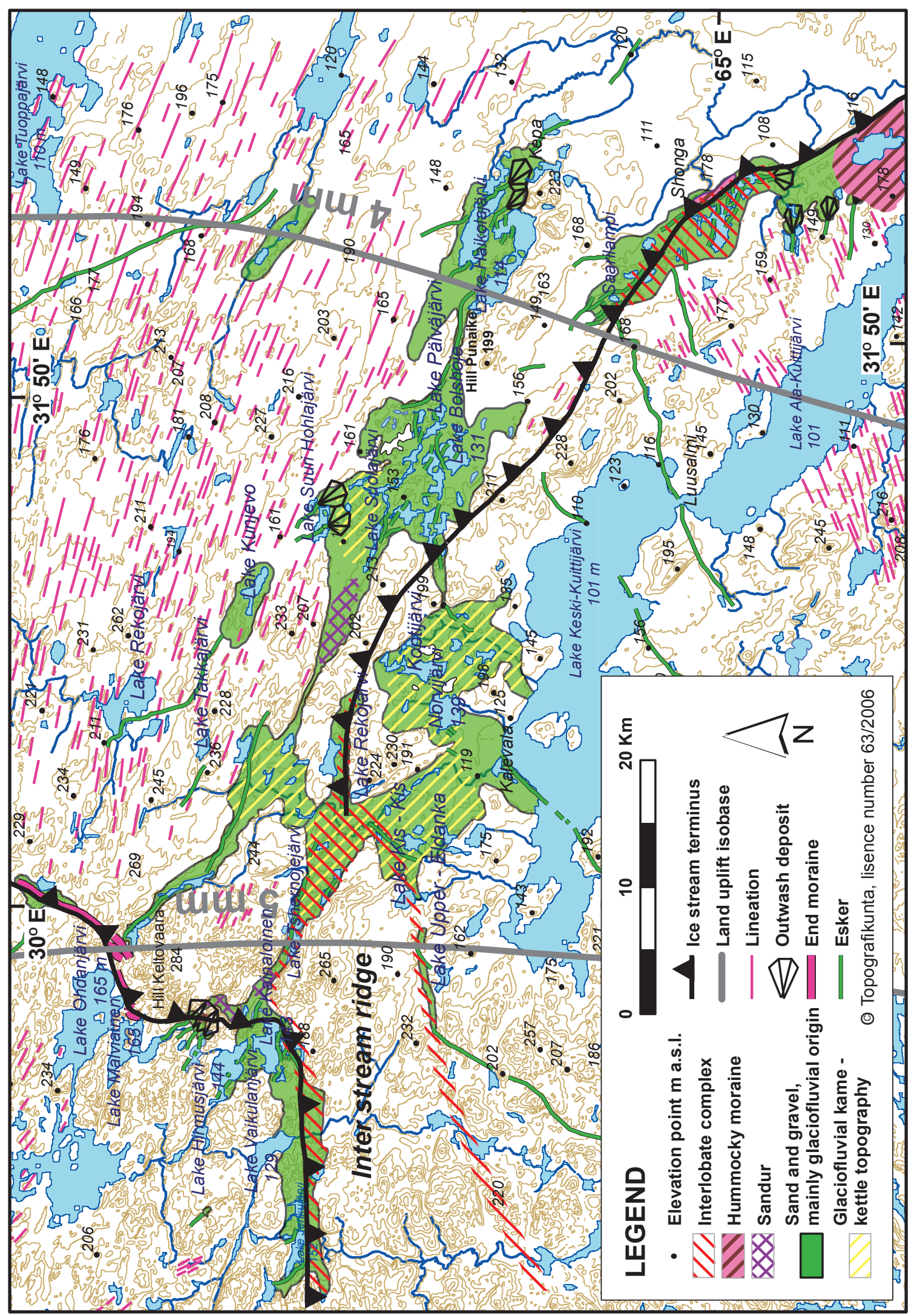


In the southeastern part of the Lake Tuoppajärvi drumlin field, an extensive glaciofluvial complex of ca. $100 \mathrm{~km}^{2}$ occurs between Lake Suolajärvi and Kepa village (Figs. 3 and 4). In this area, there are only a couple larger eskers and several esker ridges a few metres high that run east-southeast. The most prominent esker complex occurs in the eastern part of the area where an esker ridge rises 20 to $40 \mathrm{~m}$ above the surrounding terrain for $5 \mathrm{~km}$. Numerous kettle holes occur on the surface of the ridge top. The oval-shaped kettle holes are typically 20 to $30 \mathrm{~m}$ deep, $300 \mathrm{~m}$ long and their maximum width is $120 \mathrm{~m}$. The esker runs southeast where the esker ridge disappears close to Lake Haikolajärvi (Fig. 4).

Another big esker system is located in the Shonga area between the Lake Tuoppajärvi and Kalevala drumlin fields (Figs. 3 and 4). In this area, the esker system is 2 to 3 kilometres wide and the esker ridges

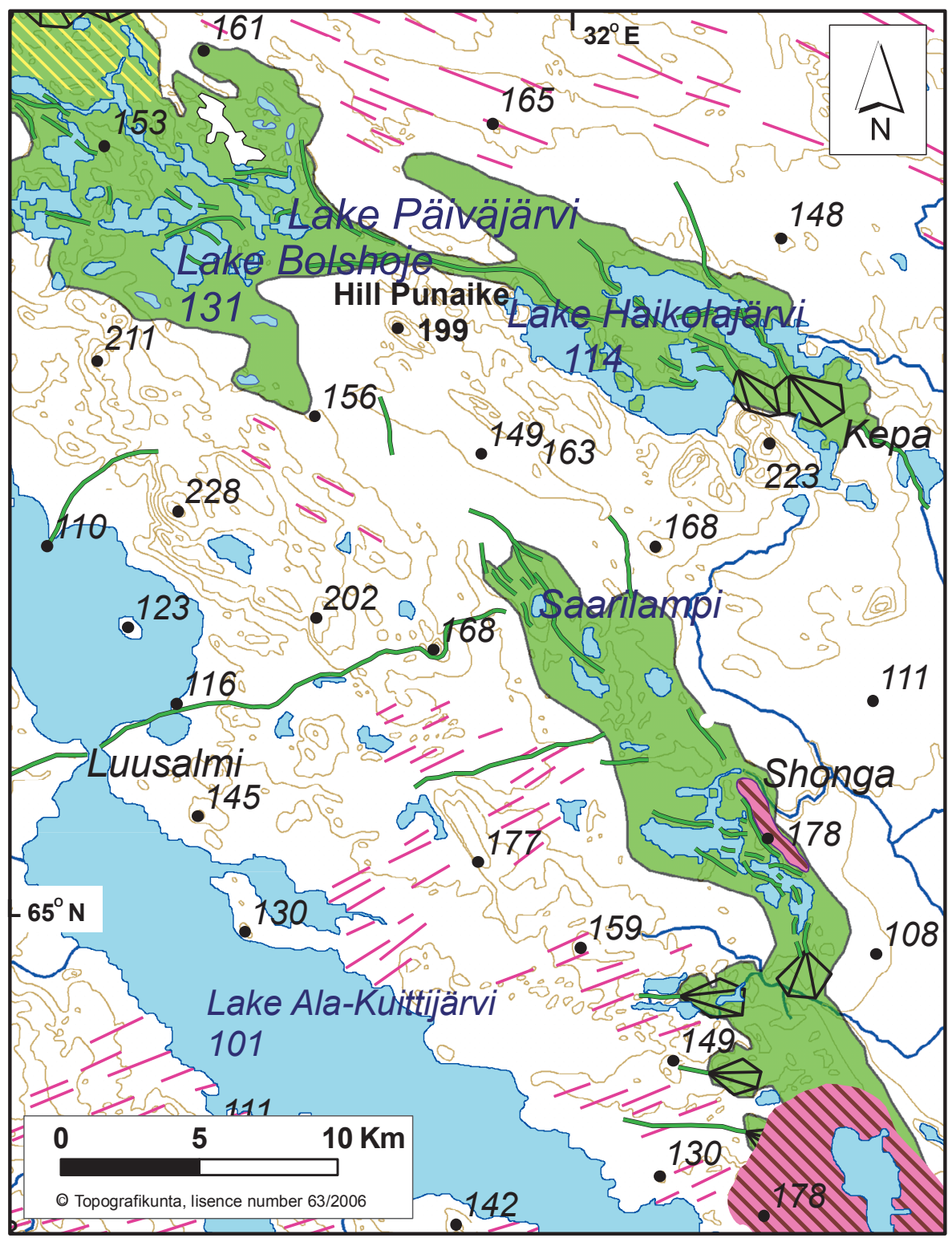

Fig. 4. Glacial geomorphology of the Lake Ala-Kuittijärvi area. For symbols see Fig. 3. 
in many places rise 40 to $50 \mathrm{~m}$ above the surrounding terrain. In this area, several eskers from the west, north-west, north and north-east join to the main ridge. The feeding eskers of the east side of the area are often covered with hummocks of stone-rich till material although the esker ridges are visible beneath the hummocky moraine.

In the area of the Kalevala drumlin field, eskers run parallel to drumlins (Fig. 3). There are three nearly continuous ridges that run for tens of kilometres from the southwest. In addition to these large continuous eskers, there are numerous smaller eskers that join the Kalevala end moraine particularly in the Shonga area (Figs. 3 and 4). Also, in the area of the Lake Pääjärvi - Lake Ohdanjärvi drumlin field, there are two relatively continuous esker ridges and a number of smaller eskers that join the end moraine zone (Figs. 3 and 6).

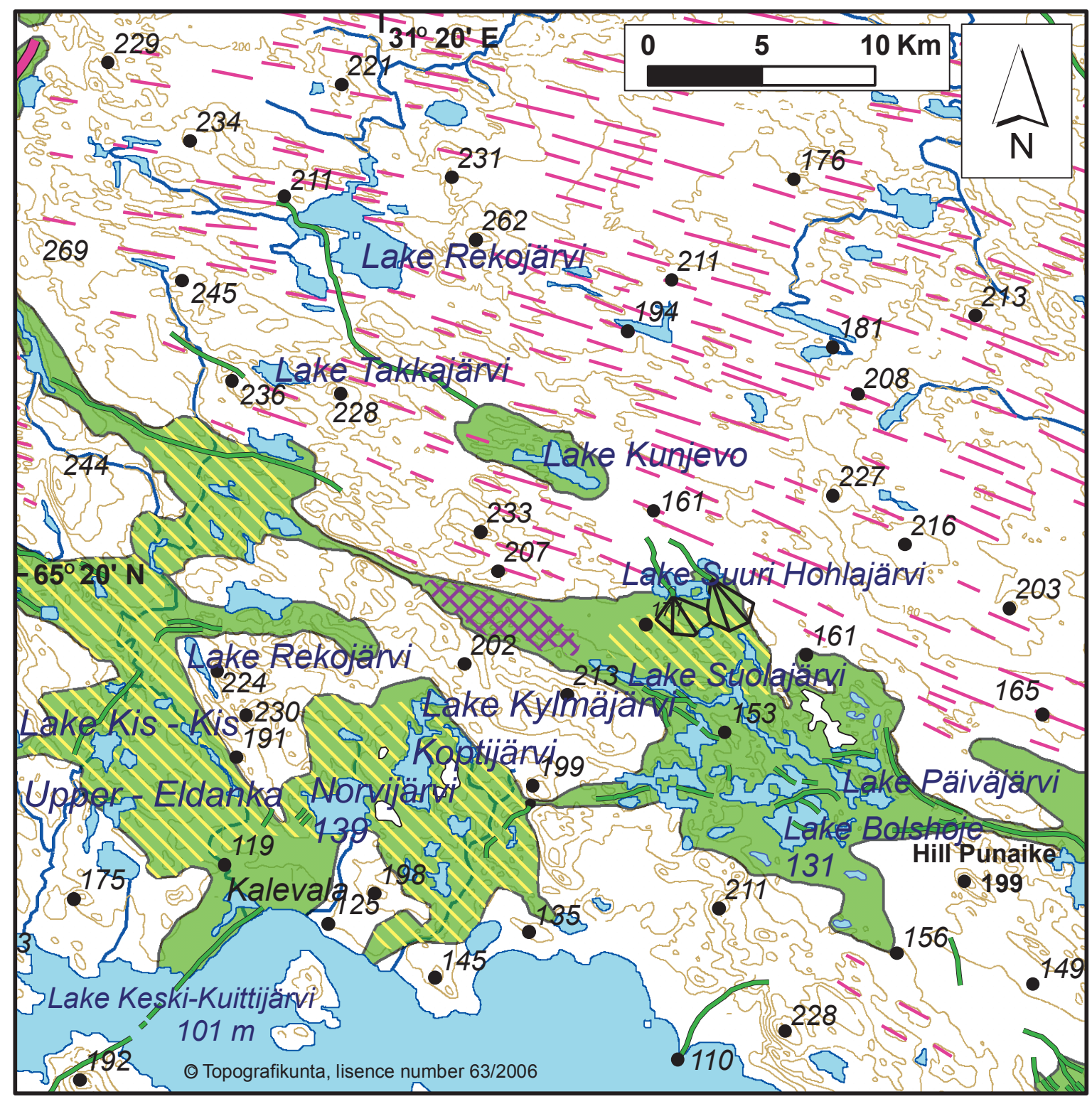

Fig. 5. Glacial geomorphology of the Lake Suolajärvi area. For symbols see Fig. 3. 


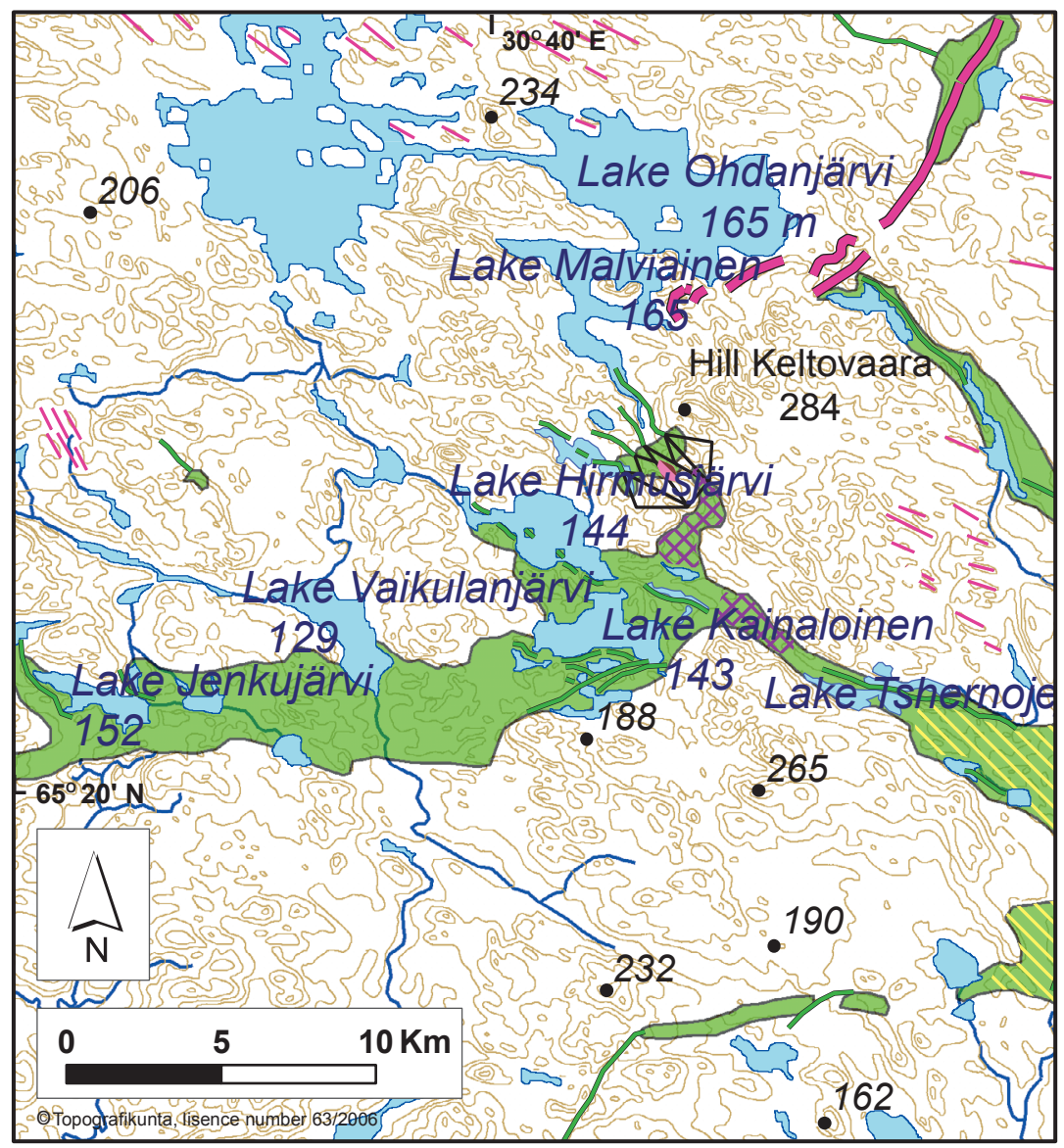

Fig. 6. Glacial geomorphology of the Lake Kainaloinen area. For symbols see Fig. 3.

\subsection{Supraglacial landforms}

There are no extensive supraglacially formed hummocky moraine areas in the study area. However, in the Shonga area, there are chaotic hummocks, $5 \mathrm{~m}$ high on average, composed of till at an altitude between 125 to $180 \mathrm{~m}$ (Figs. 3 and 4). The hummocky moraine area is $5 \mathrm{~km}$ long and ca. $500 \mathrm{~m}$ wide. There is also another hummocky moraine area further south of the Shonga area in the southeastern-most part of the study area (see Figs. 3 and 4) where individual hummocks rise up to $30 \mathrm{~m}$ high at an altitude between $125-170$ metres a.s.l.

In addition to these two hummocky moraine areas, the undulating kame - kettle topography is very common in the study area above $125 \mathrm{~m}$ a.s.l.
(Fig. 3). For example, in the Lake Koptijärvi - Lake Norvijärvi area (Fig. 3), individual kettle holes are usually 10 to $20 \mathrm{~m}$ deep, but kettle holes up to 35 $\mathrm{m}$ deep do exist. The material in the kame - kettle areas is glaciofluvial and kames and kettles occur in association with glaciofluvial formations such as eskers.

\subsection{Ice marginal landforms}

End moraine ridges composed predominantly of till occur only in the north western part of the study area, in the Lake Ohdanjärvi area (Figs. 3 and 6). These end moraines are located from $160 \mathrm{~m}$ a.s.1. $-210 \mathrm{~m}$ a.s.l. The length of individual, ca. 2 to $4 \mathrm{~m}$ high, endmoraine ridges ranges from 2 to $5 \mathrm{~km}$. 
There are several sandur plains and sandur deltas often located in the main paleovalleys of the study area above $140 \mathrm{~m}$ asl (Fig. 3). The largest sandur plain is located northwest of Lake Suolajärvi (Fig. 5). This sandur plain is $12 \mathrm{~km}$ long and $0.5 \mathrm{~km}$ to $5 \mathrm{~km}$ wide. The field observations and ground penetrating radar surveys (pers. comm. Pasanen, 2007) indicate that the topsets of sandur / sandur deltas in between the Lake Suolajärvi and Lake Päiväjärvi area are composed of coarse glaciofluvial material. In the proximal part of the sandur plain, the surface is marked with braided channel forms with longitudinal bars, kettle holes and small hummocks.

Another relatively sizeable sandur plain is situated in the Lake Tshernojejärvi valley (Figs. 3 and 6), and smaller sandurs also occur in the southeastern side of Lake Ohdanjärvi and on the southern side of Lake Bolshoejärvi. In addition to well developed sandur plains, there are also smaller supra-aquatic outwash fans, for example in the Lake Hirmusjärvi - Lake Ohdanjärvi area (Fig. 3). These outwash fans normally occur at an altitude of 150 to $200 \mathrm{~m}$ a.s.l. at the end of feeding esker ridges.

There are also several deltas and sub-aquaeous fans in the study area (Fig. 3). Most of the deltas occur at the distal end of the feeding eskers. Most of the glaciofluvial deltas are located just inside or within the Kalevala end moraine in the area between Jyskyjärvi and Shonga (Figs. 3 and 4). All of the flat delta surfaces in the Jyskyjärvi, Shonga and Kepa area occur at $123-128 \mathrm{~m}$ above sea level. A relatively flat glaciofluvial plain at the town of Kalevala, probably a subaquatic fan, lies at $110-115 \mathrm{~m}$ a.s.l.

In the Lake Suuri Hohlajärvi, Lake Suolajärvi and Lake Päiväjärvi areas, west of the Kepa area, distal parts of flat sandur delta surfaces lie at 142 to $145 \mathrm{~m}$ a.s.l. (Fig. 5).

\subsection{C-I 4 dating results}

Samples for C-14 AMS dating were obtained at three sites in the study area (Fig. 2). The description of sediments where samples were taken and the ages obtained are presented in Fig. 7 and Table 1.

Two samples (KAL-007-06 and KAL -006-06) were taken from a small lake at Röhö at an altitude of $205 \mathrm{~m}$ a.s.l (Fig. 2). The lower sample yielded an age of $9540 \pm 50 \mathrm{BP}$ (Poz-18758) (calibrated age 10 $960 \pm 205$ years) and the upper sample $9490 \pm 50 \mathrm{BP}$ (Poz-18759) (calibrated age $10730 \pm 150$ years).

One sample (TUH-009-06) was taken from a small lake at Tuhkala at an altitude of $190 \mathrm{~m}$ a.s.l (Fig. 2). The sample from the basal part of the varved gyttja yielded an age of $9030 \pm 50 \mathrm{BP}$ (Poz-18826) (calibrated age $10200 \pm 70$ years).

The third sample (JUS-001-06) was cored from the western side of the Kalevala Formation (Fig. 2) from a small pond at an altitude of 180 a.s.l. The age of this sample is $9050 \pm 50 \mathrm{BP}$ (Poz-18761) (10 225 \pm 75 years).

Table I. I4-C dating results and their calibrated ages obtained from sediments three sites in the Kalevala area.

\begin{tabular}{|c|c|c|c|c|c|c|c|c|}
\hline Sample name & $\begin{array}{l}\text { GPS / } \\
\text { location }\end{array}$ & $\mathrm{m}$ a.s.l. & $\begin{array}{l}\text { water } \\
\text { depth }\end{array}$ & $\begin{array}{l}\text { sediment } \\
\text { thickness }\end{array}$ & $\begin{array}{l}\text { sample } \\
\text { position }\end{array}$ & $\begin{array}{l}\text { laborato- } \\
\text { ry no. }\end{array}$ & $\begin{array}{l}14 \mathrm{C} \text { age } \\
\text { BP }\end{array}$ & cal $14 \mathrm{C} \mathrm{BP}$ \\
\hline \multirow[t]{2}{*}{ KAL-007-06 } & N65'26'04.0" & $205 \mathrm{~m}$ a.s.l. & $2.5 \mathrm{~m}$ & $2.7 \mathrm{~m}$ & $5.10 \mathrm{~m}^{*}$ & Poz-18759 & $9450 \pm 50$ & $10730 \pm 150$ \\
\hline & E $31^{\circ} 11^{\prime} 39.1^{\prime \prime}$ & & & & & & & \\
\hline \multirow[t]{2}{*}{ KAL-006-06 } & N65²6'04.0” & $205 \mathrm{~m}$ a.s.l. & $2.5 \mathrm{~m}$ & $2.7 \mathrm{~m}$ & $5.15 \mathrm{~m}^{*}$ & Poz- 18758 & $9540 \pm 50$ & $10960 \pm 205$ \\
\hline & E $31^{\circ} 11^{\prime} 39.1^{\prime \prime}$ & & & & & & & \\
\hline \multirow[t]{2}{*}{ TUH-009-06 } & N65'38'00.6” & $190 \mathrm{~m}$ a.s.l. & $3.0 \mathrm{~m}$ & $3.0 \mathrm{~m}$ & $5.95 \mathrm{~m}^{*}$ & Poz-18826 & $9030 \pm 50$ & $10200 \pm 70$ \\
\hline & E $30^{\circ} 36^{\prime} 11.7^{\prime \prime}$ & & & & & & & \\
\hline \multirow[t]{2}{*}{ JUS-001-06 } & N6509'14.4” & $180 \mathrm{~m}$ a.s.l. & $1.2 \mathrm{~m}$ & $4.8 \mathrm{~m}$ & $4.75 \mathrm{~m}^{*}$ & Poz-18761 & $9050 \pm 50$ & $10225 \pm 75$ \\
\hline & E31 ${ }^{\circ} 43^{\prime} 56.9^{\prime \prime}$ & & & & & & & \\
\hline
\end{tabular}

\footnotetext{
*depth below water table
} 


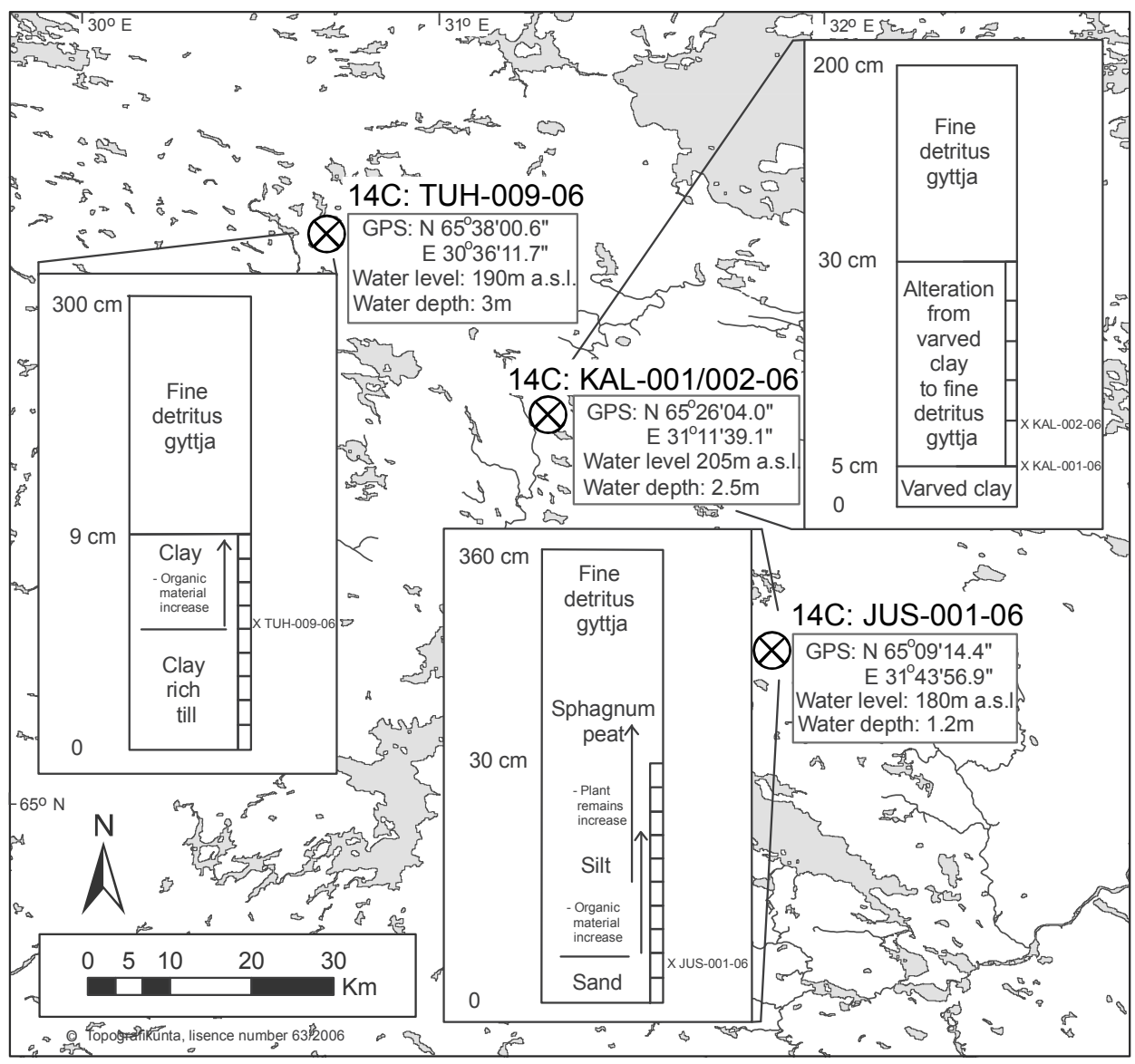

Fig. 7. Sediment logs of the cores at the three different I4-C sites in the Kalevala area.

\section{Interpretation}

\section{I. Ice streams and their termini}

Based on aerial photograph interpretation and field observations of streamlined landforms and perpendicularly orientated end moraines, it is concluded that there are landforms and erosional features created by two different ice streams during three ice-flow stages. These ice-flow stages are manifested by different orientations of fan-shaped, streamlined landforms in the Lake Tuoppajärvi area, around the Lake Kuittijärvi basin and west of Lake Ohdanjärvi (Fig. 3). Two ice streams identified in the study area are named here as the Lake Tuoppajärvi sub-ice stream (TIS) and the Lake Kuittijärvi sub-ice stream (KIS). Continuous end moraine and delta / sandur complexes are as- sociated with the streamlined landform packages in the Lake Kuittijärvi and Lake Ohdanjärvi areas but there are no prominent end moraines related to the streamlined features created by the TIS in the present study area. Therefore, it seems that during this ice flow stage the ice stream terminus was situated outside the study area.

The streamlined features in the Lake Kuittijärvi area run southwest - south southwest. These streamlined features were created by the KIS. The terminus of this ice stream can be clearly defined and it is marked by the Kalevala end moraine from Jyskyjärvi to Shonga. However, between Shonga and Lake Rekojärvi there are no well developed end moraines to mark the terminus of the KIS. However, in this area there are clear indications of an overlap zone of two 
separate ice streams. This overlap zone is manifested by glaciofluvial kame kettle topography and the feeding esker systems running from opposite directions into the overlap zone area (Fig. 3). In the northwest part of the study area, west of Ohdanjärvi, drumlins and associated end moraines define the third ice-flow stage when the ice moved from the northwest to the ice stream terminus that was situated at the end moraine zone between Lakes Pääjärvi and Ohdanjärvi (Fig. 3).

\subsection{Relative timing of the ice streams}

The study of landform associations clearly indicates that the streamlined features created by the TIS represent the first active ice flow phase in the study area. The time relationship of the flow stages between the KIS and TIS is evident east of the Kalevala end moraine belt. In this area, the streamlined features (mainly drumlins) created by the TIS indicate the ice stream flow towards the east and southeast. This implies that the streamlined features east of the Kalevala end moraine are older than linear landforms that occur inside the Kalevala end moraine (from the south-southwest and west) and the Pääjärvi end moraine further west.

It is also interesting to note that most of the feeding eskers with deltas deviate markedly from the direction of drumlins in the Tuoppajärvi area. In a number of areas, for example, south of Lake Tuoppajärvi, an esker cuts drumlinized landforms and terminates into a glaciofluvial delta. This suggests that the ice margin receded time transgressively in the area of the TIS and the ice remained warm-based during its retreat.

In the study area, there are two glaciofluvial complexes named here as interlobate complexes where the time relationship between the different ice streams can be further studied and their overlap zone identified. In the Shonga area, eskers from the TIS run from the north and northwest to the overlap zone between the TIS and KIS. In the same area, eskers from the southwest and west, that is, from the KIS, join the overlap zone forming an interlobate formation (Figs. 3 and 4). It is suggested here that this is a very strong indication of two ice masses, a relatively active
KIS and warm based but relatively passive TIS, were in contact during the time when glaciofluvial sediments were laid down between the Shonga and Lake Saarilampi areas (Fig. 3). Further south between the Shonga area to the Jyskyjärvi area, there is no indication of an overlap zone of two ice streams and in this area several deltas, end moraine ridges and hummocky moraines representing Kalevala end moraine proper mark the terminus of the KIS (Figs. 3 and 4).

In the north - northwest side of Lake Rekojärvi eskers from the KIS run from the southwest toward a huge glaciofluvial ridge (Figs. 3 and 5). There is also a large esker system running from Lake Kainaloinen via Lake Tshernojejärvi towards this huge glaciofluvial ridge from the northeast (Fig. 3). Although the age relationship of the two ice streams that formed the interlobate complex in this area is not possible to identify, the area marks the overlap zone of these two ice streams.

\subsection{The area of passive ice}

There is an area void of any streamlined features like drumlins, eskers and other glacial formations in the western part of the study area between the KIS and TIS (Fig. 3). This area is an upland area lying above $200 \mathrm{~m}$ a.s.l. where bedrock is blanketed by a thin till cover. The margins of this inter-stream area are defined by interlobate eskers (Fig. 3). In this interstream area, striations on bedrock are also highly variable indicating a complex pattern of ice flow. The northern border of the area runs from Lake Rekojärvi to Lake Kainaloinen and from there to Lake Jenkujärvi to the west (Fig. 3). Based on geomorphological interpretation and field studies, the southern border of this area runs from Lake Rekojärvi to Lake Kis-Kis and from there to the interlobate ridge of Lake Upper Eldanka towards Vuonninen village (see Fig. 3). This area void of any landforms indicates that a passive ice area existed between the two ice streams. These passive ice triangles, also called frozen bed patches, are normally located on the topographically high areas where ice is cold-based (cf. Kleman \& Glasser, 2007). 


\subsection{Sub- and supra-aquatic areas and the highest shore line in the study area}

There are several deltas and sandur deltas, kettle holes and extra-marginal meltwater channels as well as supra-aquatic landforms such as hummocky moraine areas, kame - kettle topography, sandurs and outwash fans in the study area. These landforms were used to define the highest shoreline. As noted above, most of the developed glaciofluvial deltas are located inside or within the Kalevala end moraine in the area between Jyskyjärvi and Shonga (Fig. 3). All of these deltas have been built into more or less the same water level at 123 to $125 \mathrm{~m}$ a.s.l. Similar delta levels are also found in Kepa village east of Lake Haikolanjärvi (Figs. 3 and 5). Since deltas between Jyskyjärvi and Kepa are situated at the same modern isobase (Fig. 3), it is highly likely that the deltas in these areas were built up into the same glacial lake, the level of which was at around $125 \mathrm{~m}$ a.s.l.

In the Lake Suuri Hohlajärvi, Lake Suolajärvi and Lake Päiväjärvi areas west of the Kepa area, sandur plains and sandur deltas are common. Meltwater channels and kettle holes and the pitted surfaces occur in the proximal part of the sandur deltas but the flat delta surfaces lie at the level of 142 to $145 \mathrm{~m}$ a.s.l. Based on these observations, it is concluded that the highest shoreline in the study area ranges from $125 \mathrm{~m}$ in the eastern part of the study area to $145 \mathrm{~m}$ a.s.l. in the western part of the study area.

\subsection{Deglaciation of the study area based on $\mathrm{C}-\mathrm{I} 4$ results}

C-14 dates obtained from organic-rich, lake sediments at three sites (Fig. 2) indicate minimum ages of deglaciation in the study area. The three sites where C-14 AMS dates were determined from organic gyttja are located in different parts of the study area above the highest shoreline in the supra-aquatic area and it is assumed that the organic deposition in the small lakes started only a few decades to one hundred years after the sites were deglaciated (A. Ojala, pers. comm., 2003). Solely based on C-14 results, the C-14 AMS date from the lowest part of the core at the Röhö site (10 960 \pm 205 cal. BP) indicate that the TIS deglaciated much more rapidly compared to the KIS where the C-14 date immediately inside the ice-stream terminus gave an age of $10225 \pm 75 \mathrm{cal}$ BP years. The C-14 AMS date ca. $20 \mathrm{~km}$ inside the Lake Pääjärvi end moraine gave the age $10200 \pm 70$ years, indicating that when the KIS extended to the Kalevala end moraine zone the TIS already started to retreat from the Lake Pääjärvi end moraine zone.

However, it has to be stressed here that the C-14 AMS dates obtained do not directly date the deglaciation but merely indicates the time when the areas where the dates were obtained had certainly become ice free and the areas around became covered with sparse vegetation. In any case, the C-14 AMS results do suggest that the rate of deglaciation of the TIS was more rapid compared to the KIS.

\section{Discussion}

This result confirms the previous hypothesis that two different ice streams, the Kuusamo-White Sea and the Northern Karelian ice streams, operated in the study area during the course of the last deglaciation (cf. Punkari, 1985; Ekman \& Iljin, 1991; Boulton et al., 2001). The results obtained in this study strongly suggest that the Tuoppajärvi drumlin field was formed by the Lake Tuoppajärvi sub-ice stream (TIS), which was part of the Kuusamo-White Sea ice stream. It also seems evident that the Kuusamo - White Sea ice stream, including the TIS, did not operate with a surge fan mechanism proposed by Kleman et al. (1997). This conclusion is supported by the fact that there are end moraines and eskers feeding into the ice marginal deltas in the onshore area between the present White Sea Basin and the Pääjärvi end moraine without any reorganization of the streamlined, subglacial features. This clearly indicates a successive and time transgressive retreat of the ice margin. The Lake Pääjärvi drumlin field and the associated end moraine were formed during the Lake Pääjärvi flow stage of the Kuusamo-White Sea ice stream. This flow stage is considerably younger than 
the Tuoppajärvi flow stage that formed the Tuoppajärvi drumlin field.

As mentioned above, the terminus of the Kuusamo-White Sea ice stream was situated further east of the study area in the White Sea Basin when the streamlined landforms parallel to ice flow of the TIS were formed in the Lake Tuoppajärvi area. Lunkka et al. (2007) considered that the southern terminus of the Kuusamo-White Sea ice stream (the Onega subice stream) was running from Lake Rukajärvi to Belomorsk around 12500 calendar years ago. The ice stream occupied part of the White Sea Basin or more likely terminated on shore on the west coast of the White Sea (Yevzerov, 1998).

The drumlin fields inside the Kalevala end moraine were formed by the Lake Kuittijärvi sub-ice stream (KIS), which was part of the Northern Karelia ice stream (cf. Punkari, 1985). As mentioned above, the terminus of the KIS is marked by the Kalevala end moraine from Jyskyjärvi to Shonga and from there the terminus followed the interlobate complex between the KIS and TIS as shown in Fig. 3. Based on the analysis of the streamlined features, mainly drumlin fields, striations, observations on stoss- and lee side directions of roche moutonnees and their relative age relationship in the area inside the Kalevala end moraine, it can be concluded that the ice flow stage from west-northwest to northwest, when the Lake Tuoppajärvi drumlin field was formed, pre-dates the Lake Kuittijärvi ice flow stage from the west-southwest to southwest in the study area.

During the course of the last deglaciation, the Kuusamo-White Sea ice stream terminated into a glaciolacustrine lake that extended from the present White Sea to the present study area (cf. Ekman \& Iljin, 1991; Rainio, 1995). As the ice margin retreated as far west as the study area, the geomorphological evidence, particularly the fact that longitudinal eskers running from both the TIS and the KIS areas indicate that interlobate complexes formed between these two ice streams. The evidence of eskers joining the interlobate eskers from both ice streams in the Shonga - Lake Saarilampi and Lake Rekojärvi - Tshernojärvi areas suggests that these two ice masses were possibly in contact. However, it might also be the case that the active phase of the TIS had already commenced and the ice margin had retreated westwards close to the Pääärvi end moraine zone before the KIS advanced into the area formerly occupied by the active TIS. As the KIS advanced, it overrode older landforms left behind by the TIS and created in its marginal zone the interlobate complexes. This type of imprinting of two diachronous ice streams has been described for example by De Angelis \& Kleman (2005).

The positions of the ice margin in the area of the KIS and the TIS can be reconstructed from the deltas that formed in front of the ice margin in the glacial lake. The glaciofluvial deltas with feeding eskers south of Shonga and in Kepa lie at the ca. $125 \mathrm{~m}$ level and both areas are approximately at the same southnorth trending modern isobase (Fig. 3). This means that these two areas have experienced the same uplift history after the deglaciation. It is therefore most likely that the deltas south of Shonga and around Kepa were deposited in the glacial lake that existed next to the ice margin. This ice lake must have been a part of a large ice lake that extended to the present White Sea basin since there are no areas of higher ground between the study area and the White Sea basin.

As the geomorphological evidence suggests, the TIS retreated before the KIS as the deglaciation proceeded. Based on the glaciofluvial delta levels between Kepa Village and Lake Suolajärvi in the area of the TIS (Fig. 3), it seems that the ice margin terminated into this large ice lake, the highest shoreline of which was at $145 \mathrm{~m}$ in the area of Lake Suolajärvi. Delta levels higher than $125 \mathrm{~m}$ a.s.l. are not present in the area of the KIS, which together with C-14 dating results suggests that the KIS still occupied the low land area of the Lake Kuittijärvi basins and its terminus was at the present Kalevala end moraine and continued along the interlobate formation to the north and west (Fig. 8). Longitudinal eskers, deltas, sandur deltas, sandurs and the kame-kettle topography between Kepa and Lake Ohdanjärvi were deposited during the course of the time-transgressive retreat of the TIS and these landforms were not formed in the collision zone of the TIS and KIS as previously suggested by Punkari (1985). 


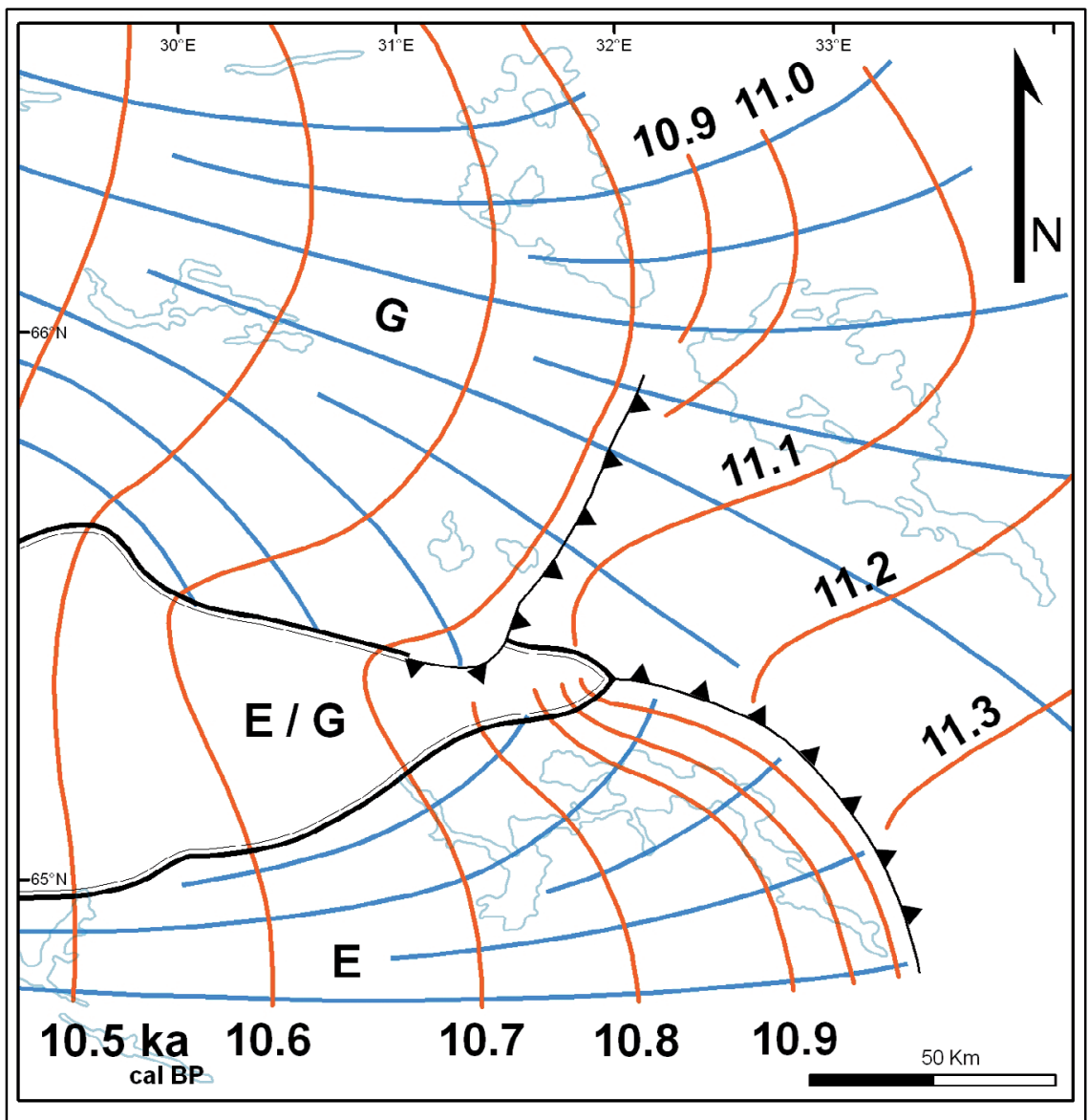

Fig. 8. Deglaciation of the Kuittijärvi and Tuoppajärvi sub-ice streams in Russian Karelia with suggested isochrones. Two ice streams (Kuittijärvi E and Kuusamo $G$ ) and the inter stream ridge (E/G) are also indicated.

There are several reconstructions of the ice retreat isolines and deglaciation chronologies for the eastern flank of the SIS including the Lake Tuoppajärvi and Lake Kuittijärvi sub-ice stream areas (cf. Hyvärinen, 1973; Kurimo, 1982; Punkari, 1985; Ekman \& Iljin, 1991; Rainio, 1995; Boulton et al., 2001; Svendsen et al., 2004; Demidov et al., 2007). In general, the deglaciation pattern and the behaviour of different ice streams in Russian Karelia are relatively well known but different reconstructions vary to some degree in detail. The precise dating of the ice retreat has been a major problem when reconstructing a detailed deglaciation history and the age estimates of the isolines have mainly been based on C-14 dates and considerations of the ice retreat rates. However, the general consensus seems to be that the Kalevala end moraine that marks the terminus of the KIS was formed ca. 11500 - 11300 calendar years ago (see Punkari, 1985; Ekman \& Iljin, 1991; Boulton et al., 2001; Svendsen et al., 2004) and the Lake Pääjärvi end moraine, which was the terminus of the Kuusamo-White Sea ice stream during the Lake Pääjärvi flow stage, was formed at ca. 9600 BP (Hyvärinen, 1973; Punkari, 1985).

As discussed above, it is not possible to accurately date the deglaciation chronology for the ice streams in the study area by using geomorphological and the C-14 dates presented above. Although a precise dat- 
ing of the last deglaciation in the Russian Karelia using palaeomagnetic, OSL, and C-14 AMS as well as sediment exposure dating is in progress by the authors, an attempt is made here to shed light on the deglaciation chronology of the study area.

As shown above, the delta deposits were built up to the contemporary ice lake level next to the ice margin in the Lake Tuoppajärvi sub-ice stream area and therefore the position of the retreating ice margin can be reconstructed relatively accurately. If we use the C-14 AMS date obtained from the Röhö site (i.e. $10960 \pm 205$ cal. BP) located in the Lake Tuoppajärvi ice stream area and consider that the average retreating velocity of the ice stream in the eastern sector of the Scandinavian Ice Sheet after the Younger Dryas chronozone was between 300 to $400 \mathrm{~m} /$ year as suggested by Boulton et al. (2001), it is possible to estimate the time when the ice margin was situated in the Kepa area.

Since the distance between the Kepa deltas and the dated sediments at Röhö is $50 \mathrm{~km}$ along the general direction of ice margin retreat (i.e. longitudinal esker chains), the ice margin was situated in the Kepa area 11200 calendar years ago based on an average retreat rate of $350 \mathrm{~m} /$ year and considering that the organic sediment deposition in sampled lakes started ca. 50 years after the ice retreat. Similar calculations indicate that the ice margin stood at Shonga-Saarilampi area ca. 11250 cal. years ago, Lake Suuri-Hohlajärvi at ca. 11100 cal. years ago, at Lake Kunjevo ca. 11000 cal. years ago and the Lake Pääjärvi end moraine was formed ca. 11000 - 10900 cal. years ago (Fig. 8).

The determination of the age of the Kalevala end moraine and the northern terminus of the Lake Kuittijärvi ice stream in the study area is more difficult. The C-14 AMS date of basal organic sediments in a small lake immediately inside the Lake Kuittijärvi ice stream terminus gave a minimum age of $10200 \pm 70$ $\mathrm{cal} \mathrm{BP}$ for the disappearance of ice in this area. However, unpublished data by the authors of varve counts and detailed palaeomagnetic measurements from the Lake Kuittijärvi sediments indicate that the ice had retreated from the Lake Kuittijärvi basin ca. 11000 calendar years ago, with a best estimate of $11200-$ 11300 calendar years ago. Similar results have also been reported by Ekman \& Iljin (1991), who suggested that the Shonga area was free of ice by 11000 calendar years ago. Therefore, it seems that the 14 -C date of $10200 \pm 70 \mathrm{cal} \mathrm{BP}$ obtained does not indicate the date when the Kalevala end moraine was formed.

Overall, these calculations suggest that the retreat of the Lake Tuoppajärvi sub-ice stream from the Shonga area to the Lake Pääjärvi end moraine took place in ca. 350 years from 11250 to 10900 calendar years ago and according to the present estimation the Kuittijärvi sub-ice stream, was at its terminus earlier than 11100 years ago. These calculations suggest that the active ice margin of the Tuoppajärvi sub-ice stream was at least in the western part of the study area and in contact with the Lake Kuittijärvi sub-ice stream.

\section{Conclusions}

The main conclusions based on the detailed aerial photograph and satellite imagery study combined with field investigations of the behaviour and timing of the Lake Kuittijärvi and the Lake Tuoppajärvi subice streams, including the dating of organic samples in the study area can be listed as follows:

1. Two ice streams, the Lake Tuoppajärvi sub-ice stream (TIS) and the Lake Kuittijärvi sub-ice stream (KIS), operated in the study area during the last deglaciation. The first active flow phase that formed highly lineated landforms in the study area were created by the TIS. After this active flow phase, TIS retreated time-transgressively from east to west across the study area. The TIS retreated from the Shonga area to the Lake Pääjärvi end moraine in ca. 350 years.

2. After the TIS flow phase, the KIS activated and advanced into the area formerly occupied by the TIS. During this flow phase, the KIS formed lineation features inside its terminus, which is marked by the Kalevala end moraine and the interlobate complexes located in the overlap zone of the two ice streams. However, it seems 
that these two ice masses were in contact at least in the western part of the study area.

3 . The age of the Kalevala end moraine is estimated to be 11200 - 11300 calendar years while the Lake Pääjärvi end moraine was formed ca. 10900 years ago.

4. Both ice streams terminated into a relatively large glacial lake extending from the Kalevala end moraine zone to the White Sea Basin. The level of this ice lake in the Kalevala end moraine zone and the Kepa area was ca. $125 \mathrm{~m}$ a.s.l. and in the western part of the study area ca. $145 \mathrm{~m}$ a.s.l.

\section{Acknowledgements}

The study was funded by the Jenny and Antti Wihuri Foundation (N.P.) and by the Finnish Academy Research Grant 210909 (J.P.L.). We thank Jussi Annanolli, Pertti Kinnunen and Miikka Paalijärvi for assisting in the field. We also thank the Karelian Research Centre in Petrozavodsk for the possibility to study aerial photographs. Pertti Sarala, Vladimir Yevzerov and an anonymous reviewer are gratefully acknowledged for their valuable comments on the manuscript. We dedicate this paper to our late colleague and friend, Dr Igor Demidov from the Institute of Geology, Karelian Research Centre, Petrozavodsk, who passed away in 2007.

\section{References}

Aario, R \& Forsström, L., 1980. Glacial stratigraphy of Koillismaa and North Kainuu, Finland. Fennia 157, 1-49.

Boulton, G.S., Dongelmans, P., Punkari, M. \& Broadgate, M., 2001. Palaeoglaciology of an ice sheet through a glacial cycle: the European ice sheet through the Weichselian. Quaternary Science Reviews 20, 591-625.

Clark. C.D., 1994. Large-scale ice moulding: a discussion of genesis and glaciological significance. Sedimentary Geology 91, 253-268.

De Angelis, H. \& Kleman, J., 2005. Palaeo-ice streams in the Keewatin sector of the Laurentide ice sheet. Annals of Glaciology 42, 135-144.

Demidov, I.N., Houmark-Nielsen, M., Kjær, K.H., Larsen, E., Lyså, A., Funder, S., Lunkka, J.P. \& Saarnisto, M., 2004. Valdaian glacial maxima in the Arkhangelsk district of northwestern Russia. In: Quaternary glaciations: extent and chronology. Developments in Quaternary Science 2. Elsevier, Amsterdam, pp. 321-336.

Demidov, I.N., Houmark-Nielsen, M., Kjær, K.H. \& Larsen, E., 2006. The last Scandinavian Ice Sheet in northwestern Russia: ice flow patterns and decay dynamics. Boreas 35, 425-443

Ekman, I. \& Iljin, V., 1991. Deglaciation, the Younger Dryas end moraines and their correlation in the Karelian A. S. S. R and adjacent areas. In: Rainio, H. \& Saarnisto, M. (eds.) Eastern Fennoscandian Younger Dryas end moraines: field conference, North Karelia, Finland Karelian ASSR, June 26 - July 4, 1991. Geological Survey of Finland, Excursion guide 32, 73-99.

Eyles, N., 1983. A landsystem approach. In: Eyles, N. (ed.) Glacial Geology: An Introduction for Engineers and Earth Scientists. Pergamon Press, Oxford, pp. 1-18.

Kleman, J. \& Glasser, N.F., 2007. The subglacial thermal organization (STO) of ice sheets. Quaternary Science Reviews 26, 585-597.

Kleman, J., Hättestrand, C., Borgström, I. \& Stroeven, A., 1997. Fennoscandian palaeoglaciology reconstructed using a glacial geological inversion model. Journal of Glaciology 43, 283-299.

Koistinen, T., Stephens, M.B., Bogatchev, V., Nordgulen, Ø., Wennerström, M. \& Korhonen, J. 2001. Geologian map of the Fennoscandian shield, scale 1: 2000000. Geological Surveys of Finland, Norwey and Sweden and the North-West Department of Natural resources of Russia.

Kurimo, H., 1982. Ice-lobe formation and function during the deglaciation in Finland and adjacent Soviet Karelia. Boreas 11, 59-78.

Larsen, E., Lysa, A., Demidov, I., Funder, S., HoumarkNielsen, M., Kjaer, K.H., \& Murray, A. S., 1999. Age and extent of the Scandinavian ice sheet in Northwest Russia. In: Late Quaternary history of northern Russia and adjacent shelves. Boreas 28, 115-132.

Lunkka, J.P., Saarnisto, M., Gey, V., Demidov, I. \& Kiselova, V., 2001. Extent and age of the Last Glacial Maximum in the southeastern sector of the Scandinavian Ice Sheet. In: Thiede, J. (ed.) The Late Quaternary stratigraphy and environments of northern Eurasia and the adjacent Arctic seas - new contributions from QUEEN. Selected papers from the annual QUEEN workshops held in Øystese, Norway, April 1999, and in Lund, Sweden, April 2000. Global and Planetary Change 31, 407-425.

Lunkka, J.P., Johansson, P., Saarnisto, M. \& Sallasmaa, O., 2004. Glaciation of Finland. In: Quaternary glaciations: extent and chronology. Developments in Quaternary Science 2. Elsevier, Amsterdam, pp. 93-100.

Lunkka, J.P., Saarnisto, M., Putkinen, N., Pasanen, A. \& Demidov, I., 2007. Younger Dryas and Early Holocene deglaciation history in the White Sea Basin area, NW Russia. Arctic Palaeoclimate and its Extremes (APEX). Planning of International Polar Year activities and preliminary results, 28-29 March, abstracts. Royal Swedish Academy of Sciences, Stockholm, p. 44. 
Niemelä, J., Ekman, I. \& Lukashov, A., 1993. Suomen ja Venäjän Federaation luoteisosan maaperä ja sen raakaainevarat $=$ Quaternary deposits of Finland and northwestern part of Russian Federation and their resources 1:1 000 000. Espoo - Petroskoi. Geological Survey of Finland - Russian Academy of Science, Institute of Geology, Petrozavodsk.

Hyvärinen, H., 1973. The deglaciation history of eastern Fennoscandia - recent data from Finland. Boreas 2, 85-102.

Payne, A.J. \& Donkelmans, P.W., 1997. Self-organization in the thermo mechanical flow of ice sheets. Journal of Geophysical Research 102, 12219-12233.

Punkari, M., 1985. Glacial geomorphology and dynamics in Soviet Karelia interpreted by means of satellite imagery. Fennia 163, 113-153.

Punkari, M., 1993. Modelling of the dynamics of the Scandinavian ice sheet using remote sensing and GIS methods. In: Aber, J.S. (ed.) Glaciotectonics and Mapping Glacial Deposits. Proceedings of the INQUA Commission on Formation and Properties of Glacial Deposits, Regina, Canadian Plains Research Center, pp. 232-250.

Punkari, M. \& Boulton, G.S., 1995. Skandinavian mannerjäätikön itäosan dynamiikka ja reuna-asemat Nuoremman Dryaksen aikana. Abstract: The dynamics and marginal positions of the Scandinavian ice sheet in its eastern part during the Younger Dryas stadial. Terra 107, 3-14

Punkari, M., 1997. Glacial and glaciofluvial deposits in the interlobate areas of Scandinavian Ice Sheet. Quaternary Science Rewiews 16, 741-753

Rainio, H., 1995. Large ice-marginal formations and deglaciation in southern Finland. In: Ehlers, J. Kozarski, S. \& Gibard, P. (eds.) Glacial deposits in North-East Europe. A.A. Balkema, Rotterdam, pp. 57-66.

Saarnisto, M. \& Lunkka, J.P., 2004. Climate variability during the last interglacial-glacial cycle in NW Eurasia. In: Battarbee, R. W., Gasse, F. \& Stickley, C.E. (eds.) Past climate variability through Europe and Africa. Developments in Paleoenvironmental Research 6. Springer, Dordrecht, pp. 443-464.

Sarala, P., 2007. Geomorphology and rapid climate change during the Late Weichelian deglaciation in southern Finnish Lapland. In: The Arctic Conference days 2007, Tromsø, Norway, 3-7 September, 2007. NGF abstracts and proceedings of the Geological Society of Norway 2. Norsk Geologisk Forening, Trondheim, p. 60.

Stokes, C.R. \& Clark, C.D., 2003. The Dubawnt Lake palaeo-ice stream: Evidence for dynamic ice sheet behaviour on the Canadian Shield and insights regarding the controls on ice-stream location and vigour. Boreas 32, 263-279

Stuiver, M. \& Reimer, P.J., 1993. Extended 14C data base and revised CALIB 3.0 14C Age calibration program. Radiocarbon 35, 215-230

Svendsen, J.I., Alexanderson, H., Astakhov, V.I., Demidov, I., Dowdeswell, J.A., Funder, S., Gataullin, V., Henriksen,
M., Hjort, C., Houmark-Nielsen, M., Hubberten, H.W., Ingólfsson, Ó., Jakobsson, M., Kjær, K.H., Larsen, E., Lokrantz, H., Lunkka, J.P., Lyså, A., Mangerud, J., Matiouchkov, A., Murray, A., Möller, P., Niessen, F., Nikolskaya, O., Polyak, L., Saarnisto, M., Siegert, C., Siegert, M.J., Spielhagen, R.F. \& Stein, R., 2004. Late Quaternary ice sheet history of northern Eurasia. In: Quaternary environments of the Eurasian North (QUEEN). Quaternary Science Reviews 23, 1229-1271.

Ukkonen, P., Jungner, H., Donner, J. \& Lunkka, J.P., 1999. New radiocarbon dates of Finnish mammoths (Mammuthus sp.). In: Reumer, J.W.F. \& Vos, J. de (eds.) $2^{\text {nd }}$ International Mammoth Conference: 200 years of mammoth research, May 16-20, 1999, Rotterdam, The Netherlands. Official conference papers, volume of abstracts, excursion guide. Natuurmuseum Rotterdam, Rotterdam, pp. 68-69.

Yevzerov, V.Ya., 1998. Deglaciation of the Kola Peninsula and the Belomorian depression. In: Quaternary Environment of the Eurasian North (QUEEN), Second QUEEN Workshop, Sankt Petersburg, Russia, 5-8 February 1998. Abstracts. European Science Foundation, Strasbourg, p. 55. 